\title{
Correlations between the slip resistance and surface roughness of ceramic floor tiles
}

\author{
Correlações entre a resistência ao escorregamento e a rugosidade superficial de pisos cerâmicos \\ Correlaciones entre la resistencia al deslizamiento y la rugosidad superficial de pavimentos
}

cerámicos

Received: 03/13/2021 | Reviewed: 03/21/2021 | Accept: 03/23/2021 | Published: 03/30/2021

\author{
Ana Virgínia Lot Lt,2 $^{1,2}$ \\ ORCID: https://orcid.org/0000-0003-3759-7034 \\ Federal University of São Carlos, Brazil \\ E-mail: anavirginia.lot@gmail.com \\ Ana Paula Margarido Menegazzo \\ ORCID: https://orcid.org/0000-0003-1222-8160 \\ Centro Cerâmico do Brasil, Brazil \\ E-mail: anapaula@ccb.org.br \\ Camila Tavares Brasileiro ${ }^{1,2}$ \\ ORCID: https://orcid.org/0000-0002-6082-404X \\ Federal University of São Carlos, Brazil \\ E-mail: camilatbrasileiro@gmail.com \\ Fábio Gomes Melchiades \\ ORCID: https://orcid.org/0000-0002-6983-4180 \\ Centro de Revestimentos Cerâmicos, Brazil \\ E-mail: tecnico@crceram.com.br \\ Anselmo Ortega Boschi ${ }^{1,2}$ \\ ORCID: https://orcid.org/0000-0003-0233-2140 \\ Federal University of São Carlos, Brazil \\ E-mail: anselmo.ufscar@gmail.com
}

\begin{abstract}
The characteristics of the floor surface profile are one of the factors that can be responsible for slip and fall accidents. To reduce the incidence of these accidents, it is essential to identify the profile features necessary for floor covering materials to be suitable for slipping risk areas. The objective of the present work was to investigate correlations between the slip resistance and the surface roughness of ceramic floor tiles. The slip resistance and the surface roughness of commercial ceramic tiles, with a diversity of surface finishes, were characterized by the pendulum method and contact profilometry, respectively. It was concluded that the presence of a large number of sharp peaks per unit of length of the profile is required for high slip resistance ceramic tiles. It was also found that the presence of waviness contributes to increasing the floors slip resistance even more. Through regression analysis, a good correlation between the pendulum results and the roughness parameter Ra was found.
\end{abstract}

Keywords: Ceramic tiles; Ceramic floors; Slip resistance; Coefficient of friction; Roughness.

\section{Resumo}

As características do perfil superficial do piso são um dos fatores que podem ser responsáveis por acidentes de escorregamento e queda. Para reduzir a incidência desses acidentes, é fundamental a identificação das características do perfil superficial dos revestimentos de pisos necessárias para que os mesmos sejam adequados para áreas de risco de escorregamento. $\mathrm{O}$ objetivo do presente trabalho foi investigar correlações entre a resistência ao escorregamento e a rugosidade superficial de pisos cerâmicos. A resistência ao escorregamento e a rugosidade superficial de pisos cerâmicos comerciais, com diversos acabamentos superficiais, foram caracterizadas através do método do pêndulo e da perfilometria de contato, respectivamente. Concluiu-se que um elevado número de picos agudos por unidade de comprimento do perfil é necessário para a alta resistência ao escorregamento dos pisos cerâmicos. Verificou-se, também, que a presença de ondulação contribui para que os pisos apresentem resistência ao escorregamento ainda mais elevada. Através de uma regressão linear, encontrou-se uma boa correlação entre os resultados do pêndulo e o parâmetro de rugosidade Ra.

\footnotetext{
${ }^{1}$ Federal University of São Carlos, Graduate Program in Materials Science and Engineering,

Rodovia Washington Luiz, km 235 SP-310, 13565-905, São Carlos, São Paulo, Brazil.

${ }^{2}$ Federal University of São Carlos, Department of Materials Engineering,

Rodovia Washington Luiz, km 235 SP-310, 13565-905, São Carlos, São Paulo, Brazil.
} 
Palavras-chave: Revestimentos cerâmicos; Pisos cerâmicos; Resistência ao escorregamento; Coeficiente de atrito; Rugosidade.

\section{Resumen}

Las características del perfil de la superficie del piso son uno de los factores que pueden ser responsables de accidentes por resbalamiento y caídas. Para reducir la posibilidad de estos accidentes, es fundamental identificar las características del perfil de las superficies de los pavimentos necesarias para que estos sean adecuados para zonas de riesgo de resbalamiento. El objetivo del presente trabajo fue investigar las correlaciones entre la resistencia al deslizamiento (resbalacidad) y la rugosidad superficial de pavimentos cerámicos. La resistencia al deslizamiento y la rugosidad superficial de baldosas cerámicas comerciales, con diversidad de acabados superficiales, se caracterizaron por el método péndulo y perfilometría de contacto, respectivamente. Se concluyó que para pavimentos cerámicos de alta resistencia al deslizamiento se requiere la presencia de un gran número de picos agudos por unidad de longitud del perfil de la superficie. También se observó que la presencia de ondulación contribuye a aumentar aún más la resistencia al deslizamiento de los pavimentos. Mediante análisis de regresión se encontró una buena correlación entre los resultados del péndulo y el parámetro de rugosidad Ra.

Palabras clave: Baldosas cerámicas; Pavimentos cerámicos; Resistencia al deslizamiento; Coeficiente de fricción; Rugosidad.

\section{Introduction}

Slip and fall accidents represent a very important issue because of their health and economic implications (Chang, Matz, Grönqvist \& Hirvonen, 2010); (Clarke et al., 2015); (World Health Organization, 2007). Annually, millions of patients are treated worldwide due to possible injuries resulting from these accidents (Muñoz, 2019). Especially in the case of the elderly, fall injuries can compromise the functional capacity to perform daily activities (Coutinho et al., 2020); (Machado et al., 2020); (Monte, et al., 2020) or even lead to fatal consequences (Coutinho et al., 2020); (Mendes, et al., 2020). In order to avoid slip and fall accidents, it is essential to keep under control the several factors involved in a slip episode. Figure 1 presents some of these factors.

Figure 1. Factors involved in slip accidents.

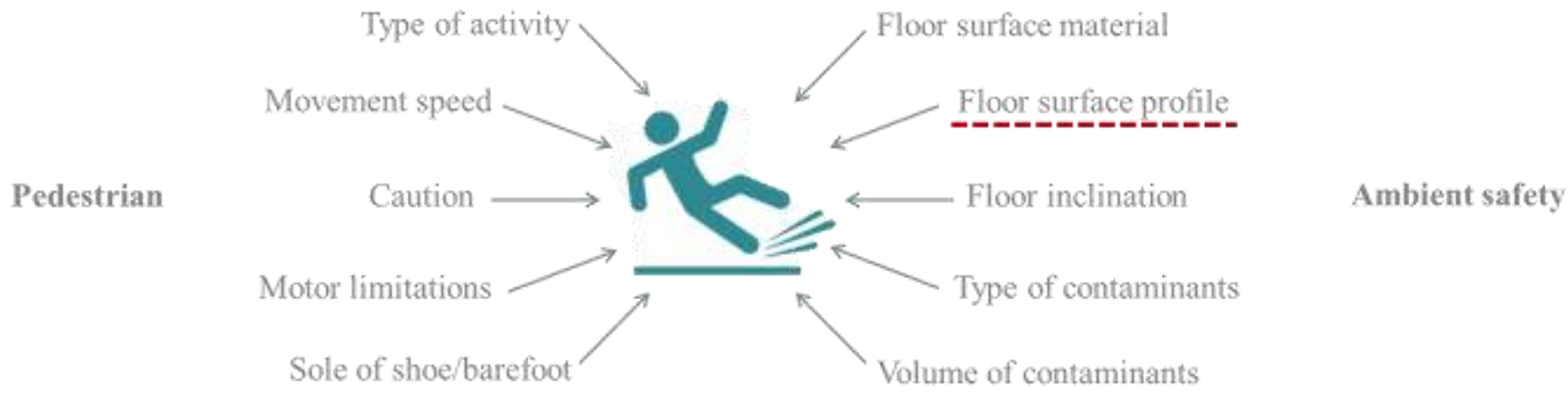

Source: Prepared by the authors from Li, Chang, Leamon, Chen (2004); Lockhart (2008); Muñoz (2019); Siegmund, Flynn, Mang, Chimich, Gardiner (2010) and Silva et al. (2018).

As can be seen, the floor surface profile of the covering material is one of the factors responsible for these accidents. Ceramic tiles are the most widely used material for floor covering (Ros-Dosdá, Celades, Vilalta, Fullana-i-Palmer, Monfort, 2019). Despite the widespread use of ceramic floor tiles, the literature about the relationship between the surface profile and the slip resistance is scarce. Therefore, to contribute to reducing the number of accidents it is important to identify which aspects of the surface profile of this covering material are more effective in promoting high slip resistance. 
The profile of a surface can be characterized by the presence of micro-irregularities, which constitute the roughness, and macro-irregularities, such as waviness and reliefs. Regarding the micro-irregularities, the specialized literature suggests that the presence of numerous peaks, preferably high and sharp, contributes to increasing the floor slip resistance by improving anchoring effects and, therefore, the friction mechanisms acting at the interface between the surface of the covering material and the shoe sole (Chang, 2004); (Chang et al., 2010); (Li et al., 2004); (Shaw, Lemon, Thorpe, 2009); (Stevension, Hoang, Bunterngchit, Lloyd, 1989). Considering the appreciable size of the shoe sole that gets in touch with the floor surface, the presence of macro-irregularities, such as waves and reliefs, reduces the contact area between the two surfaces, increasing the slip resistance of the covering material.

A major concern regarding the slip resistance of surfaces in wet conditions, one of the most critical in homes and industrial environments, is the possibility of the presence of a liquid film avoiding the contact between the shoe sole and the covering material. In these cases, the amplitude of the macroscopic and microscopic features of the profile provides accommodation volume for the liquid and increases the chances of contact between the two surfaces, enhancing the slip resistance of the covering material (Chang, 1999); (Chang, 2004); (Kim, 2017).

From the point of view of health and maintenance of the original aesthetic characteristics of the covering material, an important characteristic is its surface cleanability, the facility and efficiency of dirt and stain removal (Rambaldi, Lucchese, Engels, Bignozzi, 2019). Some features that provide traction underfoot and, therefore, enhance the slip resistance of the covering material, such as small nooks and crannies, allow the accumulation of dirt that in some cases cannot be removed by conventional methods, like mopping. Therefore, covering materials for areas of slipping risks should simultaneously present high slip resistance and cleanability. In other words, the product developers should aim for tiles with the lowest profile that provides the required level of slip resistance.

In this scenario, the objective of the present work was to investigate correlations between the slip resistance and the surface roughness of ceramic floor tiles in order to contribute to reducing the risks of slip and fall accidents when this type of covering material is used.

\subsection{Surface finishes for high slip resistance of ceramic floors}

Macro and microscopic profile features can be explored in the design of covering materials to be used in slipping risk areas.

In the macroscopic scale, the presence of raised patterns, such as the dots shown in Figure 2, is quite common. This strategy reduces the contact area between the shoe sole and the covering material, contributing to enhancing the slip resistance of the latter. However, for this strategy to work, the slip resistance of the elevated areas should be high. Therefore, even though the scale of this sort of configuration is far beyond roughness, that is the object of this work, the contributions of this study still apply. 
Figure 2. Surface profile designed for use in slipping risk areas.

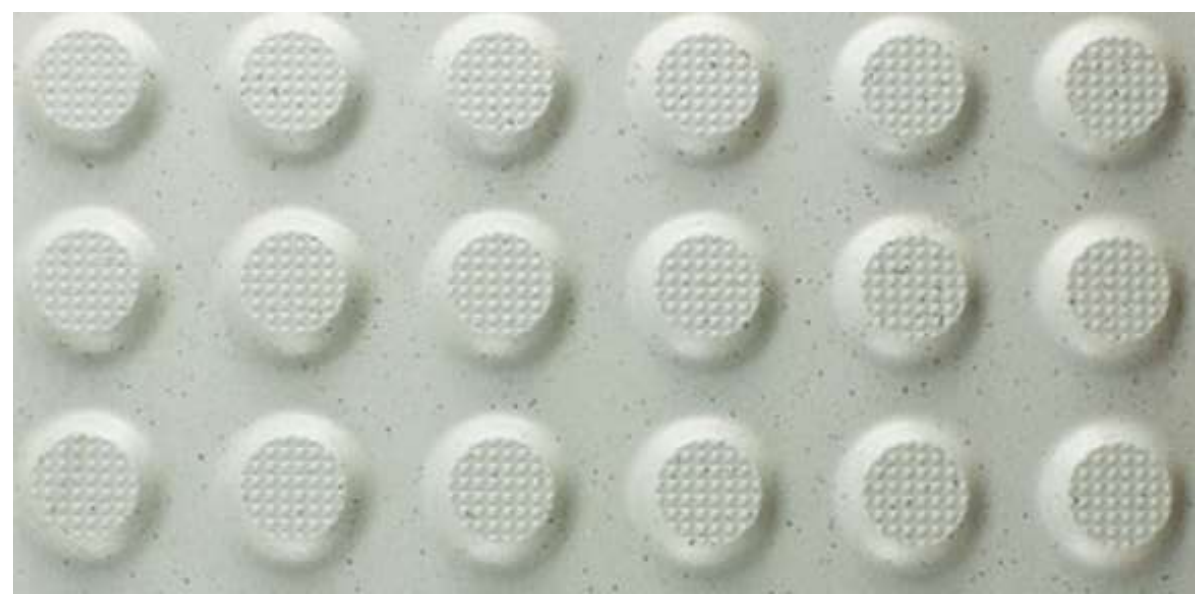

Source: Foshan Jianqiu Ceramics Co. Ltd. (2021)

Roughness can be naturally found in untreated and unglazed surfaces or produced by the presence of small crystals present on the surface of matt glazes. Rough wavy surfaces, also called texturized, combine macro and microscopic features that should contribute to increasing the slip resistance. These wavy surfaces can be produced by some decoration techniques, such as glaze spray, in which some of the pulverized drops overlap. Another possibility is the dry application of coarse-grained glazes, known as grits, to the surface of tiles that are already covered by a layer of another fine-grained glaze. Textures can also be produced by the application of glaze in specific points of the surface of the tiles and by the use of pressing molds with texturized surfaces. To produce some special textures a combination of these techniques can be used.

\subsection{Characterization of surface finish}

Regarding the surface profile characterization, contact profilometry has been widely used. The contact profilometer is illustrated in Figure 3.

Figure 3. Mechanical contact profilometer.
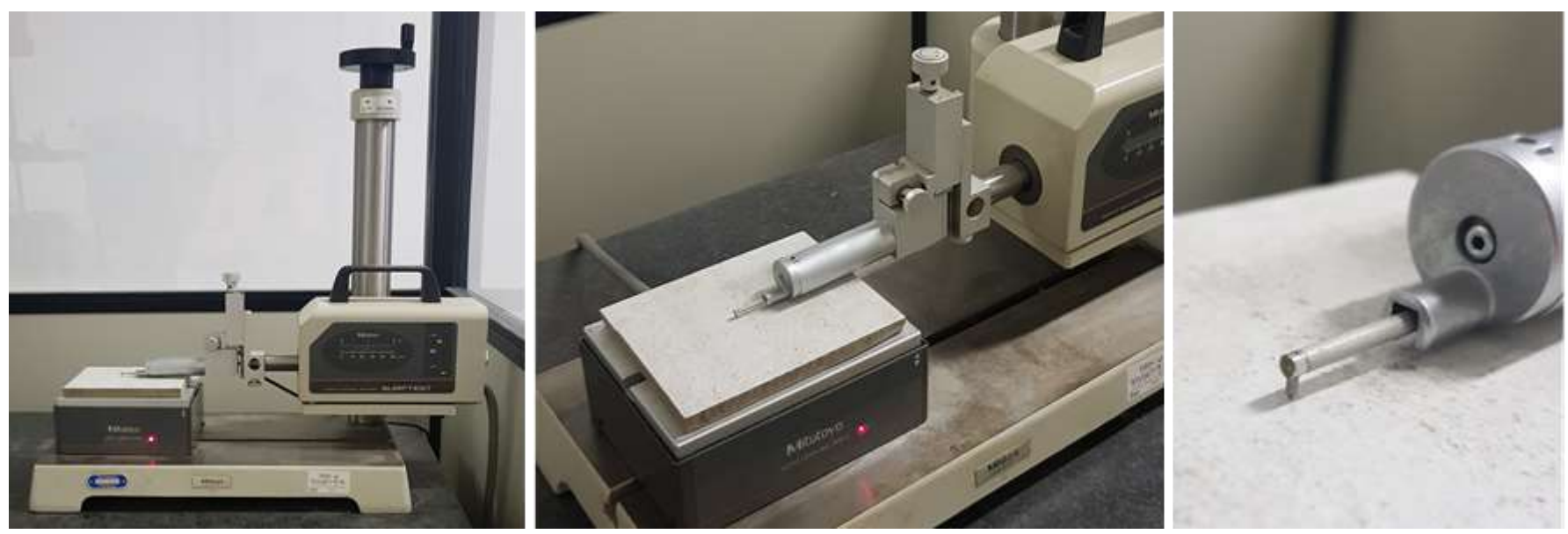

Source: Authors (2021).

The equipment has a thin metallic stylus that slides over a predetermined length of the surface, of the order of a few millimeters. The vertical movements of the stylus are measured in relation to a reference, defined as the zero value on the 
vertical axis. The movements of the stylus are registered and converted into a two-dimensional primary profile of the surface, as illustrated in Figure 4.

Figure 4. Primary and filtered profiles obtained by the mechanical contact profilometer.

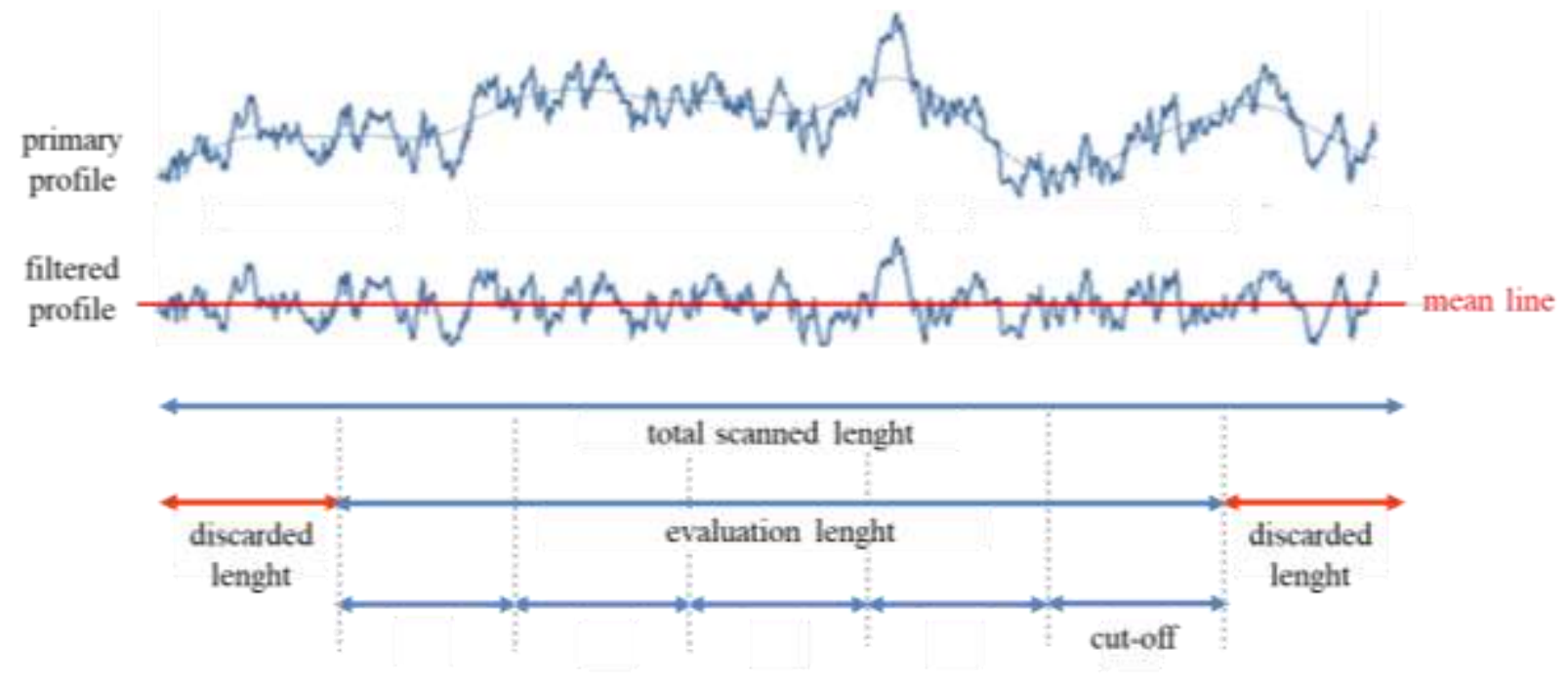

Source: Prepared by the authors from Carpinetti, Gonçalves Filho, Porto, Jasinevicius (2000).

As can be seen in Figure 4, to avoid the distortions produced by the acceleration and deceleration of the car that moves the probe over the sample, the initial and final sections are discarded. To prevent the distortions produced by form deviation, the intermediate segment, called the evaluation length, is split into 5 equal fragments called cut-offs. Then, the profilometer software removes the profile irregularities with wavelengths higher than the length of these cut-offs. In the center of the obtained filtered profile, the mean line is traced, so that the sum of the upper and lower areas in relation to this line are equivalent.

Based on this profile, several parameters that quantify different aspects of surface roughness are determined. The possible correlations between these parameters and the slip resistance of covering materials have been the subject of many studies (Chang, 2004); (Chang, et al., 2010); (Kim, 2017); (Li et al., 2004); (Shaw et al., 2009).

In two of these studies, recently published in some of the most respectable magazines dedicated to this subject, still and all, report difficulties in finding a single surface parameter as an indicator of friction studies (Chang, et al., 2010); (Kim, 2017).

\subsection{Characterization of slip resistance}

Several methods, based on different measurement principles, have been used to assess floor slipperiness. Among them, the pendulum, mainly because its results presented a good correlation with slip and fall accidents (Clarke et al., 2015), is adopted by relevant standards all over the world (ASTM, 2018); (UNE, 2003); (AS, 2013); (BSI, 2002). The pendulum device was designed to simulate the shoe heel strike contact with the floor. The arm of the pendulum, equipped with a rubber slider, is released from a given height. The slider scans a length of $124 \mathrm{~mm}$ of the surface and, then, the rebound height, named Pendulum Test Value (PTV), approximately the dynamic friction coefficient x 100 (Clarke et al., 2015); (Muñoz, 2019), is registered. The floors are classified according to their PTV for use in different areas of slipping risks (United Kingdom Slip Resistance Group, 2000). 


\section{Methodology}

To achieve the aims of this work, commercial ceramic floor tiles, with a variety of surface finishes, were characterized in relation to their slip resistance and surface roughness.

Table 1 and Figure 5 present the selected samples and a brief description of their characteristics based on commercial information.

Table 1. Selected ceramic floor tiles and a brief description of their surface characteristics.

\begin{tabular}{ll}
\hline Samples & Surface description \\
\hline Glossy 1 & Glossy smooth polished surface \\
Glossy 2 & Glossy smooth glazed polished surface \\
Glossy 3 & Glossy smooth glazed surface \\
Satin 1 & Satin smooth glazed surface \\
Satin 2 & Satin smooth glazed surface \\
Glossy Wavy 1 & Glossy wavy surface, produced by the pulverization of glaze drops \\
Glossy Wavy 2 & Glossy wavy surface, produced by the pulverization of glaze drops \\
Natural & Natural porcelain tile surface (no finish) \\
Matt & Matt gritty glazed surface with dry touch \\
ABS & Surface with ABS texture (produced with matt glaze applied in specific points) \\
Wood & Glazed textured surface with wood look \\
Stone & Glazed textured surface with stone look \\
\hline
\end{tabular}

Source: Authors (2021).

Figure 5. Representative images of the surfaces of the selected commercial ceramic floor tiles.

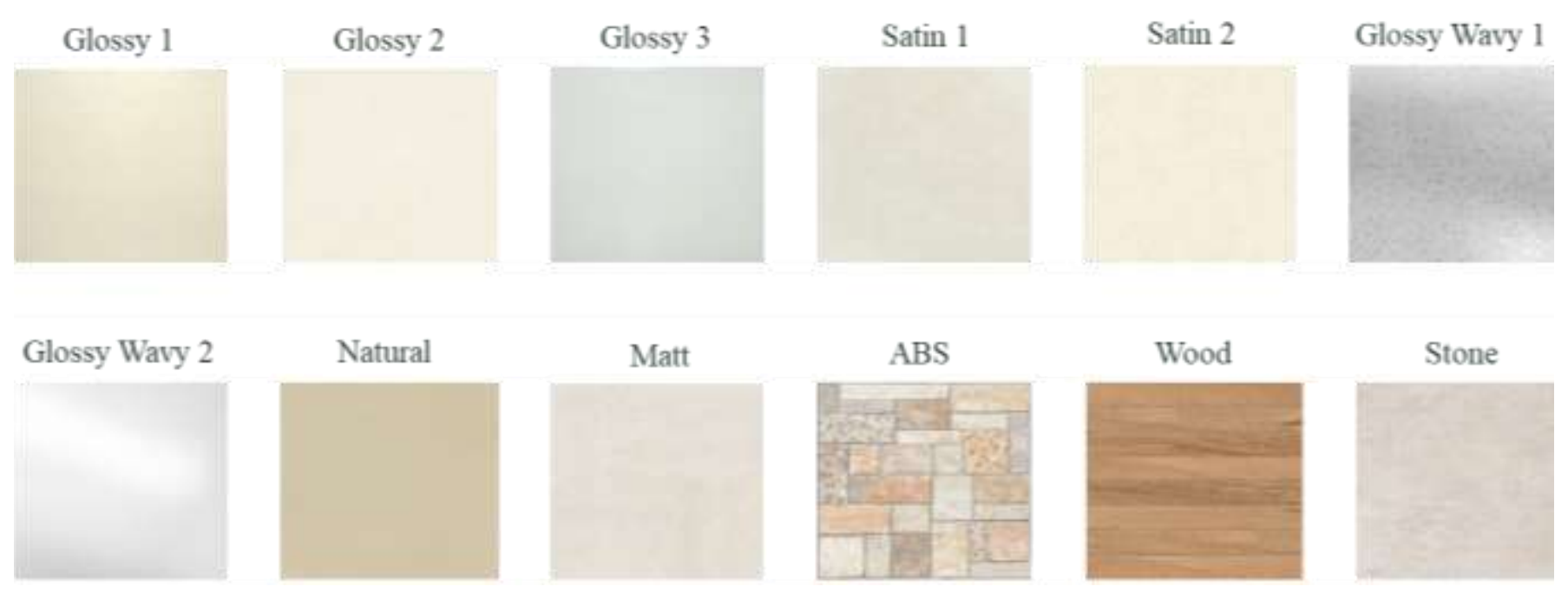

Source: Authors (2021).

The slip resistance of the surfaces was evaluated through the pendulum method, previously described, according to procedures reported in the UNE ENV 12633 standard (UNE, 2003). The measurements were done on wet surfaces. 
The surface roughness was characterized with a contact profilometer Mitutoyo SurfTest SURFPAK Series. A length of $17.5 \mathrm{~mm}$ was scanned in each surface. Segments of $2.5 \mathrm{~mm}$ were discarded at the beginning and the end of the total length for obtaining a $12.5 \mathrm{~mm}$ profile. The cut-off used was $2.5 \mathrm{~mm}$. From the filtered profile, the parameters presented in Table 2 were determined. Six measurements were carried out for each surface for the calculus of the average parameters.

Table 2. Roughness parameters determined by the contact profilometer.

\begin{tabular}{cl}
\hline Parameter & Description \\
\hline Ra & arithmetic mean of the absolute values of the profile deviations from the mean line \\
IR & profile length ratio: actual profile developed length / evaluated length \\
Rt & average height of the five highest peaks and five deepest valleys of the profile \\
Ry & average of peak to valley height in each cut-off length \\
Rpm & average of the maximum peak height in each cut-off length \\
Rvm & average of the maximum valley depth in each cut-off length \\
$\mathrm{R} 3 z$ & mean height from third highest peak to third lowest valley in each cut-off length \\
$\mathrm{R} 3 \mathrm{y}$ & maximum height of third highest peak to third lowest valley in each cut-off length \\
$\Delta \mathrm{a}$ & arithmetical mean of surface slope \\
$\lambda \mathrm{a}$ & average profile wavelength \\
$\mathrm{Sm}$ & mean spacing between profile peaks at the mean line \\
$\mathrm{Ku}$ & kurtosis of the surface, an indicative of the sharpness of the profile \\
$\mathrm{Sk}$ & skewness of the profile, an indicative of the symmetry of the profile amplitude
\end{tabular}

Source: Prepared by the authors from Chang (2004) and Mitutoyo America Corporation.

Subsequently, correlations between each of these roughness parameters and the slip resistance of the samples were investigated through linear regressions, performed in Microsoft Excel. In this type of analysis, the best equation $y=a x+b$ which allows the prediction of a variable y (PTV) from a variable x (roughness parameters) is determined. Thereafter, the coefficient of determination, $\mathrm{R}^{2}$, ranging from 0 to 1 , expresses how well the statistical model fits the data. The closer the fitted values ( $\mathrm{y}$ values predicted by the equation) are to the actual y values, the closer $\mathrm{R}^{2}$ is to 1 , which indicates a good correlation between the variables $\mathrm{x}$ and $\mathrm{y}$. To validate the correlation, the randomness of the points must be observed when plotting the residual values (differences between the fitted and actual y values) as a function of the fitted values.

\section{Results and Discussion}

\subsection{Slip resistance $x$ Roughness}

The slip resistance of samples listed in Table I, evaluated by the pendulum method, are presented in Figure 6. The dashed line represents PTV $=36$, the minimum recommended for slipping risk areas. 
Figure 6. Pendulum Test Value (PTV) of the samples listed in Table I.

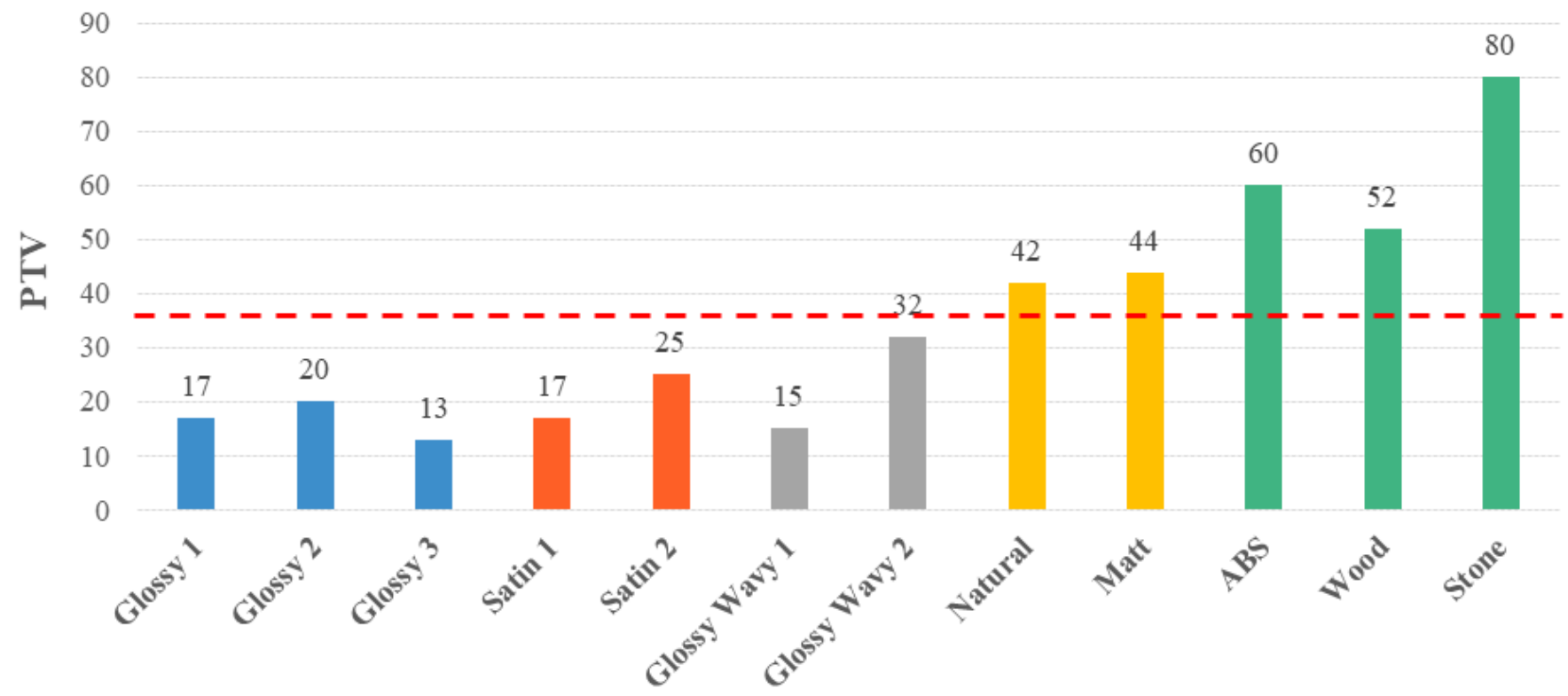

Source: Authors (2021).

As can be seen in Figure 6, due to the great variety of surface characteristics, a wide variation of slip resistance values was obtained. Only samples Natural, Matt, ABS, Wood and Stone surpassed the minimum recommended value for slipping risk areas.

Figure 7 presents the filtered profiles of the samples, obtained by the contact profilometer. To ease the analyses of the results, the surface profiles were grouped in accordance with their characteristics: Group 1 - Glossy and Satin; Group 2 Glossy Wavy; Group 3 - Natural and Matt; and Group 4 - ABS, Wood and Stone. 
Figure 7. Representative filtered surface profiles of the samples listed in Table I, obtained by the contact profilometer.
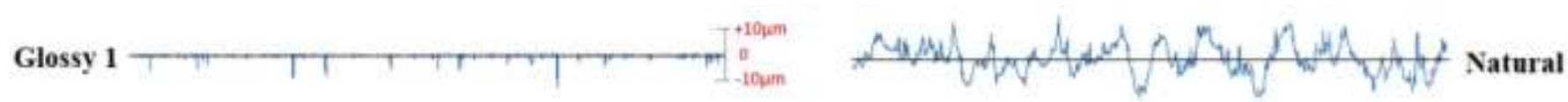

Glossy 2

Glossy 3
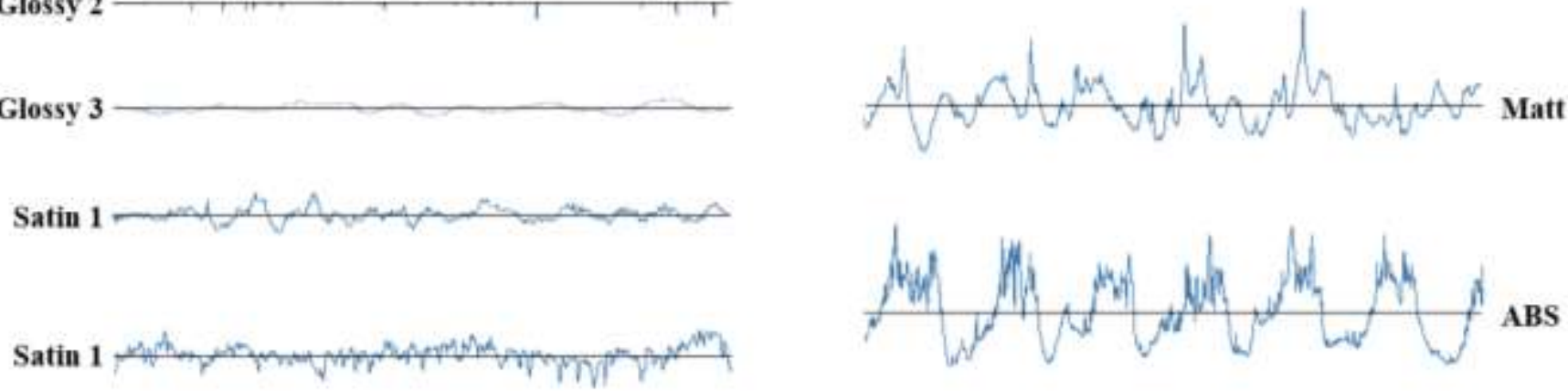

ABS
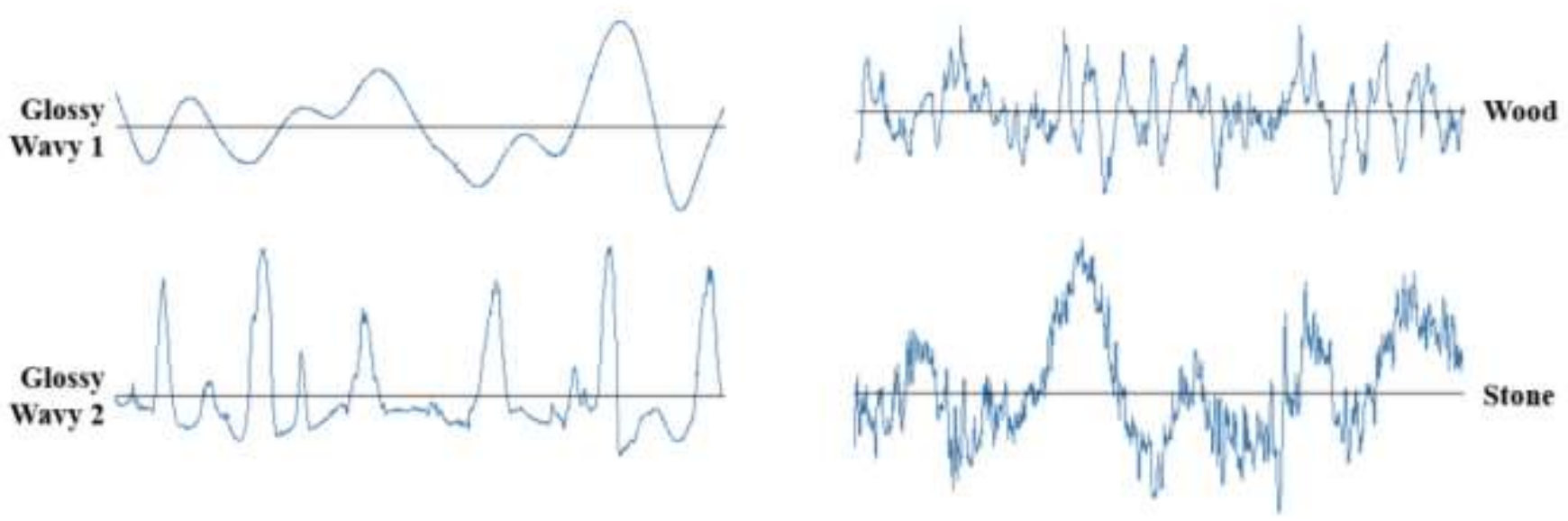

Source: Authors (2021).

In the sequence, the surface profiles and PTV results are analyzed to identify possible correlations.

Group 1 - Glossy and Satin: The profiles of these samples, which presented low PTV values, are characterized by smaller amplitude in comparison to those of the other surfaces.

Group 2 - Glossy Wavy: These samples with high amplitude profiles, basically constituted by waviness protuberances, also did not reach the minimum PTV value recommended for use in slipping risk areas. Despite the higher amplitude of the peaks in these samples, in comparison to the profiles of the samples of the Group 1, the PTV of the surface Glossy Wavy 1 was similar to the value found for Glossy 3, the lowest result for the first group. This suggests that waviness elements, by themselves, are not effective in producing high slip resistance. Another interesting aspect, regarding the Glossy Wavy samples, which from a commercial point of view are classified as similar, is the difference between their PTV results: 15 for Glossy Wavy 1 and 32 for Glossy Wavy 2. Although the amplitude of the profile is similar in the two surfaces, the number of peaks per unit length and their sharpness are considerably higher in Glossy Wavy 2 in comparison with Glossy Wavy 1 , suggesting that, in addition to amplitude, these characteristics also play an important role in slip resistance.

Group 3 - Natural and Matt: The PTV of these samples surpassed the recommended value for use in slipping risk areas. In terms of the number of peaks, the profiles of these samples are similar to those of the samples Satin 1 and 2. However, the amplitude of the peaks in these samples is considerably higher, suggesting that the combination of an elevated number of sharp peaks per unit of length and high amplitude leads to high slipping resistance. 
Group 4 - ABS, Wood and Stone: The PTV values of these samples were the highest of all. The profiles of samples ABS and Stone, besides presenting a high number of sharp peaks per unit length, also present regularly spaced waviness protuberances. The surface profile of the Wood sample, which also presents a profile with a high number of sharp peaks per unit length and a considerable amplitude, but without the regularly spaced protuberances, presented a lower PTV in comparison to ABS and Stone samples. These results suggest that the combination of profile features - the high number of sharp peaks per unit length and regularly spaced waviness protuberances - is the most effective strategy, among those adopted for the studied samples, in producing high slip resistance surfaces.

From the above, it is possible to conclude that a high amplitude profile, with a great number of sharp peaks per unit of length, is required for the high slip resistance of ceramic tiles. Additionally, when these requirements are met, it was found that the presence of waviness contributes to increasing the slip resistance of the surfaces even more.

\subsection{In search of correlations:}

Table 3 presents the roughness parameters of the samples listed in Table I, calculated from the data collected by the profilometer. 
Research, Society and Development, v. 10, n. 4, e4410413865, 2021

(CC BY 4.0) | ISSN 2525-3409 | DOI: http://dx.doi.org/10.33448/rsd-v10i4.13865

Table 3. Roughness parameters calculated from the results obtained by the contact profilometer. The parameters were grouped accordingly to the profile aspect which they quantify. The PTV results were also included for comparison.

\begin{tabular}{|c|c|c|c|c|c|c|c|c|c|c|c|c|}
\hline & Glossy 1 & Glossy 2 & Glossy 3 & Satin 1 & Satin 2 & $\begin{array}{c}\text { Glossy } \\
\text { Wavy } 1\end{array}$ & $\begin{array}{c}\text { Glossy } \\
\text { Wavy } 2\end{array}$ & Natural & Matt & ABS & Wood & Stone \\
\hline PTV & 17 & 20 & 13 & 17 & 25 & 15 & 32 & 42 & 44 & 60 & 52 & 80 \\
\hline \multicolumn{13}{|l|}{ Overall } \\
\hline \multicolumn{13}{|l|}{ Roughness } \\
\hline $\mathrm{Ra}(\mu \mathrm{m})$ & 0.3 & 0.1 & 1.2 & 2.4 & 2.6 & 10.2 & 8.0 & 4.9 & 6.3 & 9.1 & 8.2 & 12.7 \\
\hline IR & 1.01 & 1.00 & 1.00 & 1.00 & 1.01 & 1.00 & 1.01 & 1.02 & 1.01 & 1.03 & 1.03 & 1.09 \\
\hline \multicolumn{13}{|l|}{ Amplitude } \\
\hline $\mathrm{Rz}(\mu \mathrm{m})$ & 5.0 & 2.7 & 3.2 & 6.6 & 10.2 & 36.0 & 26.2 & 16.0 & 19.9 & 22.2 & 28.4 & 39.2 \\
\hline $\mathrm{Rt}(\mu \mathrm{m})$ & 13.4 & 7.9 & 7.4 & 19.3 & 21.4 & 73.6 & 63.4 & 39.6 & 46.0 & 51.0 & 60.2 & 93.3 \\
\hline Ry $(\mu \mathrm{m})$ & 8.4 & 5.7 & 5.4 & 13.2 & 16.5 & 44.4 & 43.6 & 28.9 & 35.5 & 40.9 & 49.0 & 70.2 \\
\hline $\operatorname{Rpm}(\mu \mathrm{m})$ & 0.4 & 0.2 & 2.7 & 7.2 & 7.3 & 23.2 & 29.2 & 15.7 & 20.6 & 24.0 & 27.1 & 36.6 \\
\hline $\operatorname{Rvm}(\mu \mathrm{m})$ & 8.0 & 5.5 & 2.7 & 6.0 & 9.1 & 21.2 & 14.3 & 13.2 & 14.9 & 16.9 & 21.7 & 33.7 \\
\hline $\mathrm{R} 3 \mathrm{z}(\mu \mathrm{m})$ & 4.5 & 2.1 & 1.1 & 4.4 & 9.6 & 2.4 & 11.7 & 13.4 & 12.6 & 8.6 & 26.4 & 30.8 \\
\hline R3y $(\mu \mathrm{m})$ & 6.5 & 3.2 & 1.7 & 6.6 & 11.7 & 3.4 & 20.1 & 18.3 & 18.6 & 16.2 & 33.1 & 42.2 \\
\hline \multicolumn{13}{|l|}{ Inclination } \\
\hline$\Delta \mathrm{a}\left({ }^{\circ}\right)$ & 2.4 & 1.2 & 0.9 & 2.8 & 5.0 & 2.3 & 4.2 & 7.4 & 4,7 & 7.8 & 9.7 & 17.3 \\
\hline \multicolumn{13}{|l|}{ Spacing } \\
\hline$\lambda \mathrm{a}(\mu \mathrm{m})$ & 49 & 32 & 457 & 297 & 186 & 1520 & 665 & 243 & 489 & 405 & 305 & 265 \\
\hline $\operatorname{Sm}(\mu \mathrm{m})$ & 86 & 63 & 635 & 348 & 185 & 1436 & 773 & 271 & 576 & 673 & 325 & 267 \\
\hline \multicolumn{13}{|l|}{$\begin{array}{l}\text { Kurtosis/ } \\
\text { skewness }\end{array}$} \\
\hline $\mathrm{Ku}$ & 47.7 & 122.5 & 2.2 & 2.4 & 3.0 & 2.3 & 4.0 & 2.8 & 2.8 & 2.4 & 2.9 & 2.6 \\
\hline Sk & -6.1 & -7.4 & 0.0 & 0.1 & -0.3 & 0.0 & 1.1 & 0.1 & 0.2 & 0.3 & 0.1 & 0.2 \\
\hline
\end{tabular}

Source: Authors (2021).

References to good correlations between several roughness parameters, such as $\mathrm{Ra}, \mathrm{Rz}$ and Rpm, and the slip resistance of covering materials can be found in the literature (Chang, 2004); (Chang et al., 2010); (Kim, 2017); (Li et al., 2004); (Shaw et al., 2009). However, none of these studies were dedicated exclusively to ceramic floor tiles. Due to peculiarities of the fabrication process of these products and the usual presence of a surface glaze layer that melts during the firing stage, ceramic floors can present particular characteristics that deserve to be investigated. 
In this work, in the search for relationships between PTV values and several parameters listed in Tabel III, the regression analysis method was used. As previoulsy stated, in this type of analysis, the parameter $\mathrm{R}^{2}$, known as the coefficient of determination, expresses how well two variables are correlated. Reasonable correlations between PTV values and some parameters listed in Table III were found. However, none of them were as good as the results obtained for the Ra parameter, one of the most commonly used and simplest roughness parameters. Also known as the mean roughness of the surface, Ra represents the arithmetic mean of the absolute values of the profile deviation from the mean line of the profile. The correlations found between PTV and this parameter are shown below.

Figure 8 presents the linear regression between PTV and Ra values for all the studied samples.

Figure 8. PTV and Ra values for all the characterized samples, listed in Table I, with the correspondent linear regression line and the coefficient of determination $\mathrm{R}^{2}$.

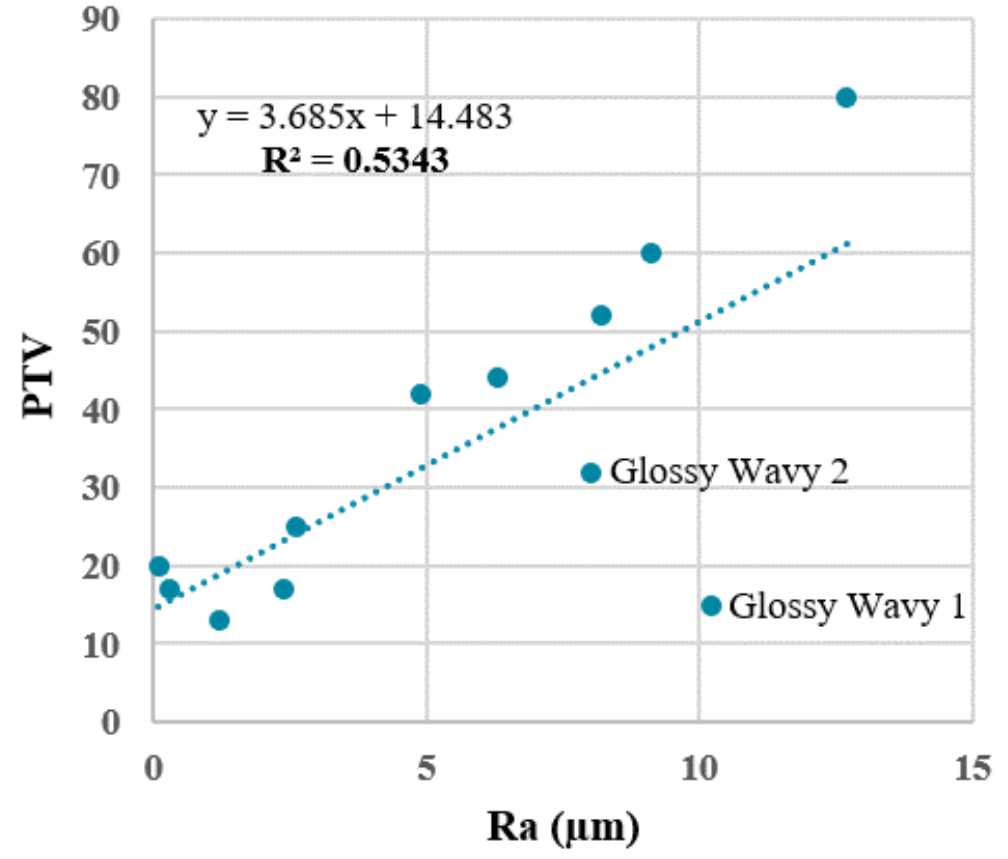

Source: Authors (2021).

As can be seen in Figure 8, a relatively low coefficient of determination $\left(R^{2}=0,5343\right)$ was obtained when considering the data corresponding to all the samples. The visual analysis of the graph shows that the samples responsible for the low coefficient of determination were the Glossy Wavy. The PTV results of these surfaces are considerably lower than the values predicted from their Ra parameters, using the equation exhibited in Figure 8. The amplitude of the waviness in their profiles contributed to their high Ra values. Nevertheless, despite that, due to the absence of roughness peaks, these samples presented low slip resistance.

Figure 9 presents the linear regression between PTV and Ra values for the studied samples, not considering the surfaces Glossy Wavy 1 and Glossy Wavy 2. 
Figure 9. PTV and Ra values for all characterized samples, listed in Table I, except samples Glossy Wavy 1 and 2 , with the correspondent linear regression line and the coefficient of determination $\mathrm{R}^{2}$.

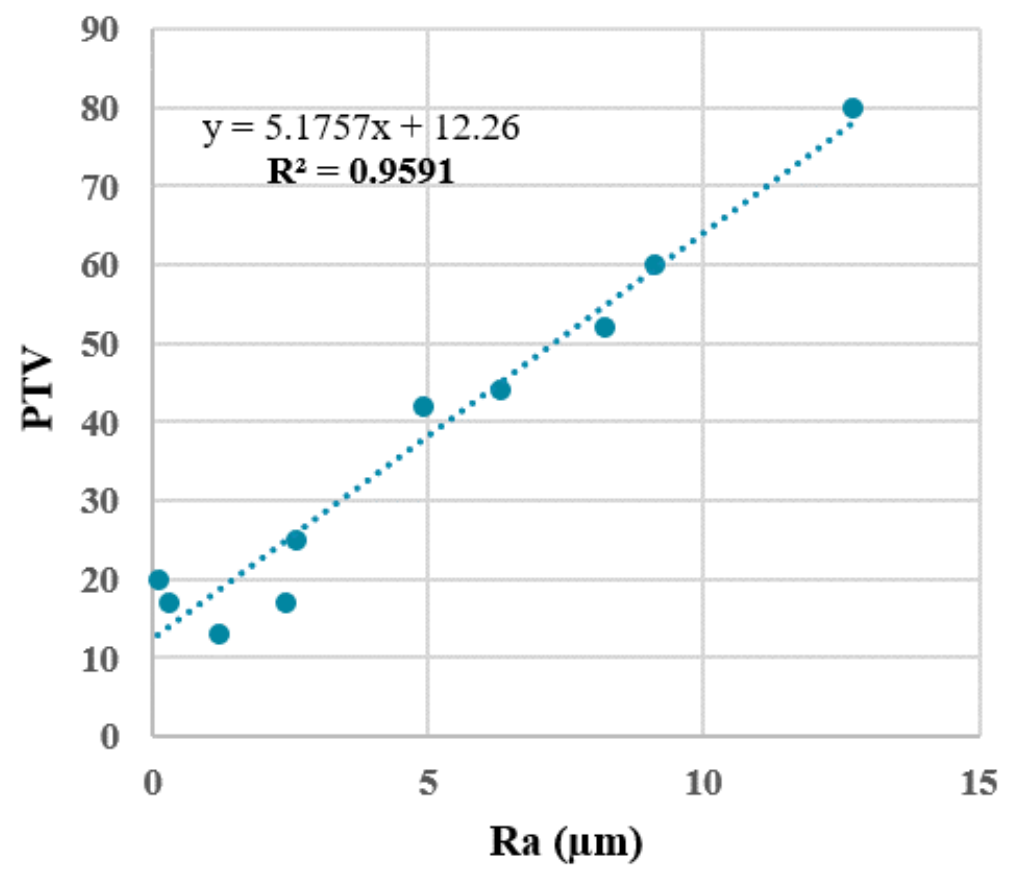

Source: Authors (2021).

As observed, when these samples were not considered, the fitting of the linear regression was quite good $\left(\mathrm{R}^{2}=\right.$ 0,9591). The randomness of the points in the correspondent residual plot confirmed the good fit of the statistical model represented by the equation presented in Figure 9.

It is worth mentioning that, considering the set of samples without the Glossy Wavy surfaces, it was also possible to find a good correlation between the PTV and the parameter Rpm $\left(R^{2}=09535\right)$. This reinforces the relevance of the presence of high peaks in the profiles of the surfaces for their high slip resistance.

Finally, Figure 10 presents the linear regression between PTV and Ra values only for the samples for which PTV surpassed the minimum value recommended for use in areas of slipping risks. 
Figure 10. PTV and Ra values for the characterized samples that presented the minimum PTV required for slipping risk areas $(\mathrm{PTV}=36)$, with the correspondent linear regression line and the coefficient of determination $\mathrm{R}^{2}$.

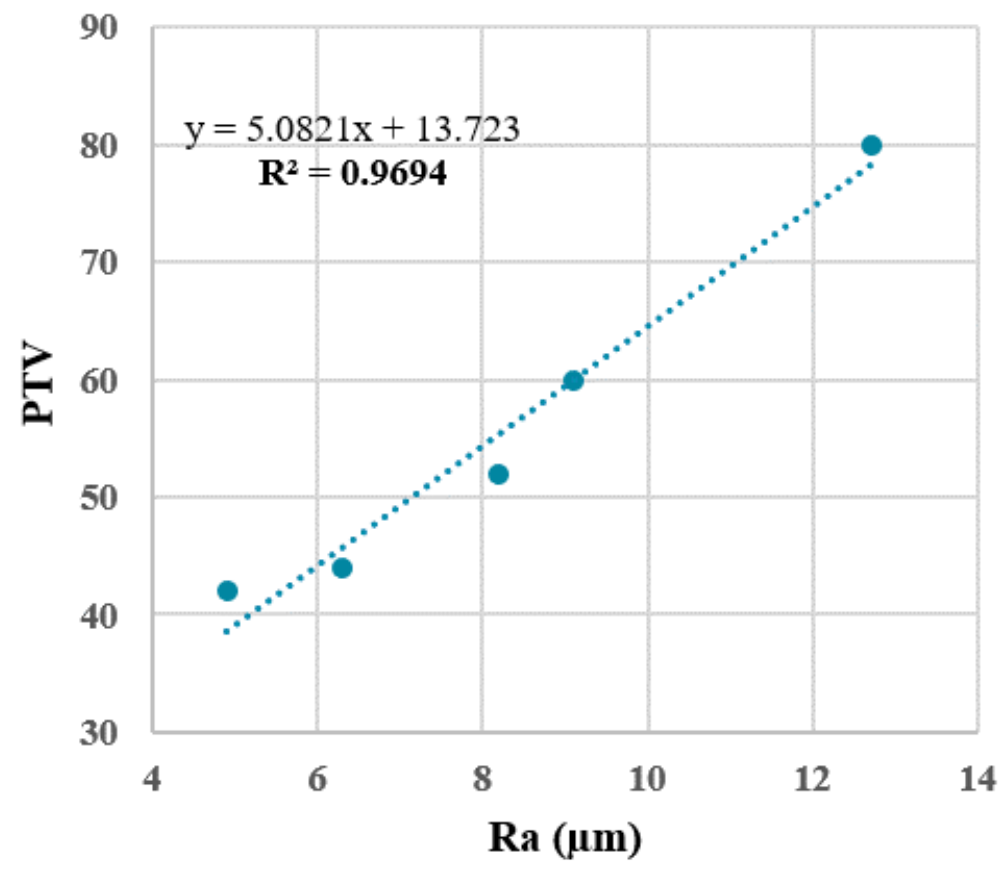

Source: Authors (2021).

In this case, as shown in Figure 10, the fitting was even better $\left(R^{2}=0,9694\right)$. To confirm the quality of this fitting, a residual plot is presented in Figure 11.

Figure 11. Residual Plot of the linear model represented by the equation presented in Figure 10.

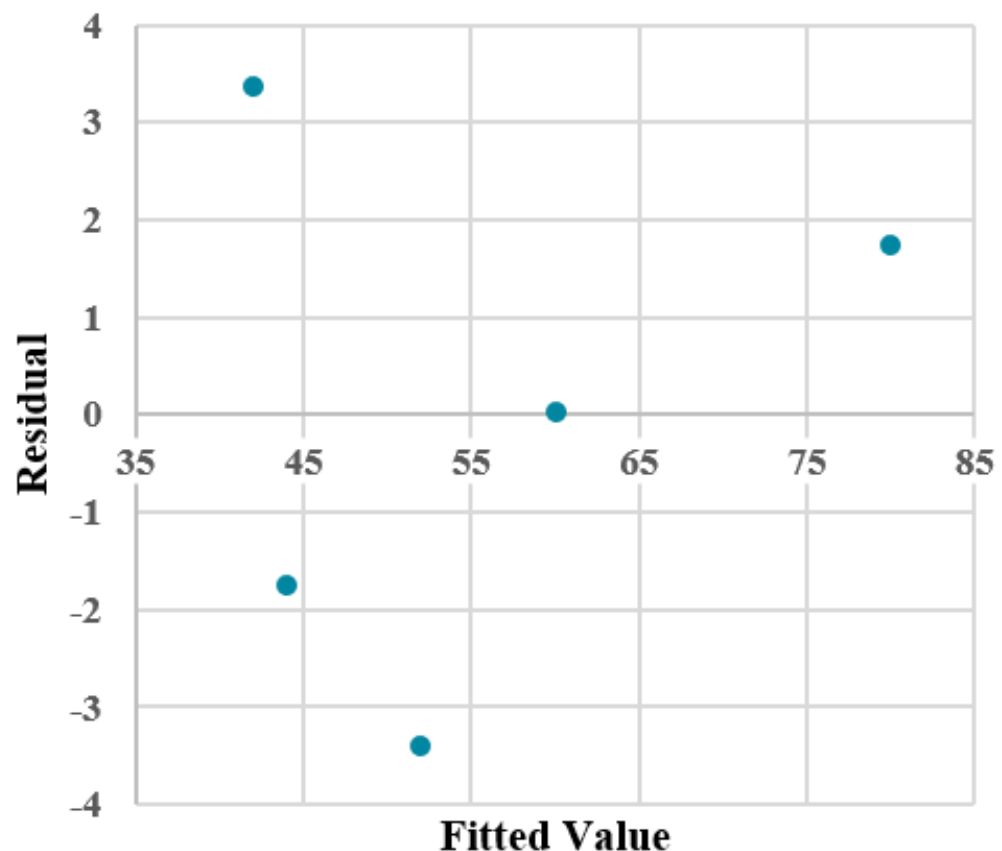

Source: Authors (2021). 
As can be seen, the residual plot shows a fairly random pattern, indicating that the linear model represented by the equation in Figure 10 provides a good fit for this set of data.

Considering only these five surfaces, Ra stood out as the only parameter, among all the studied, for which such a strong correlation with PTV was found.

From the above, it can be concluded that the mean roughness of the surface, Ra, is the main profile characteristic in determining the slip resistance of the samples of the ceramic floor tiles studied. In that sense, one of the most important experts in this subject stated that: "Understanding the role of surface roughness in friction can help floor manufacturers improve floor designs and can also help the end-users properly select floor surfaces appropriate for their applications as well as assess the safety of existing floor surfaces (Chang, 2004)". Therefore, establishing a simple statistical model that well correlates the slip resistance of ceramic tiles and one of the most commonly used and simplest roughness parameters, Ra, represents a very important contribution to the development and use of ceramic floor tiles suitable for slipping risk areas, minimizing the number of slip and fall accidents.

\section{Conclusion}

The wet slip resistance and the surface roughness of a variety of commercial ceramic tiles, with a considerable diversity of surface finishes, were evaluated, by the pendulum method and contact profilometry, respectively. Comparing the slip resistance values and the surface profiles obtained for the samples, it was possible to conclude that a profile of considerable amplitude, with the presence of a large number of sharp peaks per unit of length, is required for the high slip resistance of ceramic tiles. The results also suggested that the presence of waviness protuberances regularly spaced in the profile of the surfaces contributes to increasing the slip resistance even more.

Regarding the relationship between the slip resistance, measured by the pendulum method, and surface roughness parameters, through the regression analysis method, except for two of the twelve studied samples, a very good fitting between the slip resistance data and a roughness parameter, $\mathrm{Ra}$, was achieved $\left(\mathrm{R}^{2}=0,9591\right)$. When just the samples for which slip resistance values surpassed the minimum value required for use in slipping risk areas, PTV $=36$, the fitting was even better $\left(\mathrm{R}^{2}=\right.$ 0,9694). The validity of the fittings of the linear regression models was confirmed through residual plots.

\section{Acknowledgments}

This study was financed in part by the Coordenação de Aperfeiçoamento de Pessoal de Nível Superior - Brasil (CAPES) - Finance Code 001.

It was also supported by the Conselho Nacional de Desenvolvimento Científico e Tecnológico - Brasil (CNPq) Process: 142276/2016-2.

We would also like to extend our especial gratitude to the Group of Ferroic Materials of the Physical Department of the Federal University of São Carlos for providing the profilometer for the study.

\section{References}

AS. Standards Australia. (2013). AS 4586, Slip resistance classification of new pedestrian surface materials.

ASTM. American Society for Testing and Materials. (2018). ASTM E. 303-93, Standard Test Method for Measuring Surface Frictional Properties Using the British Pendulum Tester.

BS British Standards Institution. (2002). BS 7976. Pendulum testers. 
Research, Society and Development, v. 10, n. 4, e4410413865, 2021

(CC BY 4.0) | ISSN 2525-3409 | DOI: http://dx.doi.org/10.33448/rsd-v10i4.13865

Carpinetti, L. C. R., Gonçalves Filho, E. V., Porto, A. J. V., Jasinevicius, R. G. (2000). Rugosidade Superficial: Conceitos e Princípios de Medição, Serviço Gráfico USP - EESC, São Carlos.

Chang, W.-R. (1999). The effect of surface roughness on the measurement of slip resistance. International Journal of Industrial Ergonomics, 24 (3), $299-313$.

Chang, W.-R. (2004). Preferred surface microscopic geometric features on floors as potential interventions for slip and fall accidents on liquid contaminated surfaces, Journal of Safety Research, 35 (1), 71-79.

Chang, W.-R., Matz, S., Grönqvist, R., \& Hirvonen M. (2010). Linear regression models of floor surface parameters on friction between Neolite and Quarry tiles. Applied Ergonomics, 41 (1), 27-33.

Clarke, J. D., Hallas, K., Lewis R., Thorpe, S., Hunwin, G., \& Carré, M. J. (2015). Understanding the friction measured by standardised test methodologies used to assess shoe-surface slip risk. Journal of Testing and Evaluation, 43 (4), 723-734.

Coutinho, A. C. C., Rolim, U. L. T. P., Lopes, M. L. H., Corrêa, R. G. C. F., Santos, L. H., \& Rolim, P. F. (2020). Analysis of the occurrence of falls in patients hospitalized in a high complexity hospital in northeast Brazil. Research, Society and Development, 9 (8), e555985805.

Foshan Jianqiu Ceramics Co. Ltd. (2021). https://www.alibaba.com/product-detail/porcelain-tactile-tile-ceramic-floor-tile300X300mm_1007186890.html.

Kim, I.-J. (2017). Investigation of Floor Surface Finishes for Optimal Slip Resistance Performance. Safety and Health at Work, 9 (1), 17-24.

Li, K.W., Chang, W.-R., Leamon, T. B., \& Chen, C. J. (2004). Floor slipperiness measurement: friction coefficient, roughness of floors, and subjective perception under spillage conditions. Safety Science, 42 (6), 547-565.

Lockhart. T. E. (2008). An integrated approach towards identifying age-related mechanisms of slip initiated falls. Electromyogr Kinesiol, 18 (2) $205-217$.

Machado, E. A., Santo, F. H. E., Ribeiro, M. N. S., Silvino, Z. R., Cardoso, R. S. S., Almeida, E. G. R., \& Aranha, J. S. (2020). Aging and fall prevention: overview of the nursing team of a Transition Hospital. Research, Society and Development, 9 (10), e2749108566.

Mendes, I. C., Santos, S. M. S., Júnior, J. C. C. L., Santos, M. M. S., Barreto, J. A. P. S., Silva, K. T., Pinheiro, E. L. T., Neto, I. F. S., Pinheiro, S. L. F., Pinheiro, R. B., Fernandes, L. S., Guedes, I. C. P., Bezerra, P. S., Pereira, T. C., Macedo, L. R., Lima, A. E. T., \& Silva, P. N. (2020). Falls rate in the elderly assisted by a Family Health Strategy in Juazeiro do Norte/Ceará. Research, Society and Development, 9 (8), e537986038.

Mitutoyo America Corporation, Mitutoyo Surface Roughness Measuring System SurfTest SURFPAK Series - Manual 4796-3G, Series 178.

Monte, J. A., Gomes, V. M. S. A., Silveira, T. M. V., Arruda, L. Q., Carvalho, V. C. P., Barros, M. L. N., \& Uchôa, E P. B. L. (2020). Influence of virtual rehabilitation with X-box® on the risk of fall s in the elderly. Research, Society and Development, 9 (10), e3049108638.

Muñoz, A. (2019). Problemática del resbalamiento en pavimentos cerámicos. Memoria presentada para optar al grado de doctora por el Programa de Doctorado en Tecnologías Industriales y Materiales Escuela de Doctorado de la Universitat Jaume I.

Rambaldi, E., Lucchese, B., Engels, M., \& Bignozzi, M. C. (2019). Evaluation of durability and cleanability performances of protective treatments for lapped ceramic tiles - Part 2. International Journal of the Applied Ceramic Technology, 16 (2), 625-637.

Ros-Dosdá, T., Celades, I., Vilalta, L., Fullana-i-Palmer, P., \& Monfort, E. (2019). Environmental comparison of indoor floor coverings. Science of The Total Environment, 693, 133519.

Shaw, R., Lemon, P., \& Thorpe, P. (2009). Development of a more accurate assessment of roughness parameters for flooring. Health and Safety Executive Research Report 732.

Siegmund, G. P., Flynn, J., Mang, D. W., Chimich, D., \& Gardiner, J. C. (2010). Utilized friction when entering and exiting a dry and wet bathtub. Gait Posture, 31 (4), 473-478.

Silva, G., Beltrán, A., Muñoz, A., Escrig, A., Llobell, C., Sanchís, M., \& Lillo, G. (2018). Combinaciones optimizadas de pavimento cerámico y calzado para entornos laborales. Anais Qualicer'18 (Congreso Mundial de la Calidad del Azulejo y el Pavimento Cerámico).

Stevension, M. G., Hoang, K., Bunterngchit, Y., \& Lloyd, D. (1989). Measurement of slip resistance of shoes on floor surfaces, Part 1: Methods. Journal of Occupational Health and Safety, 5 (2), 115-120.

UNE. Asociación Española de Normalización. (2003). UNE ENV 12633. Method to assess the slip/slide resistance of polished and unpolished flooring.

United Kingdom Slip Resistance Group. (2000). The Measurement of Floor Slip Resistance - Guidelines Recommended by the UK Slip Resistance Group. United Kingdom.

World Health Organization. (2007). WHO global report on falls prevention in older age. Geneva. 53. 